\title{
4 Migration, membership regimes and social policies: a view from global history ${ }^{1}$ Leo Lucassen
}

In the last decade the unprecedented massive rural to urban migrations ${ }^{2}$ in China have attracted scholarly attention, especially of those who are interested in citizenship. Although these Chinese peasants, drawn to the bright lights and factories of cities like Shanghai and Dongguan, are internal migrants, they are treated almost as foreigners. After the economic liberalization by Deng Xiaoping in the late 1970s, rural Chinese were allowed to leave their villages and work and (de facto) settle in cities. They are excluded, however, from the social rights (benefits, education, healthcare) that urbanites enjoy. The basis for this unequal treatment is the 'hukou system', put in place in the 1950s, which binds the Chinese population to its administrative units and which was originally aimed at surveiling the mobility of Chinese citizens and preventing urbanization. ${ }^{3}$ This system of internal controls was adopted from the Soviet Union. Its propiska system, established by the Russian czars in the nineteenth century and reintroduced by Stalin in December 1932, along with a mandatory residence permit (propiska), regulated (and still does) the settlement of Russians in cities. ${ }^{4}$

Whereas Chinese and Russian peasants were excluded from urban services and institutions, this practice was radically different for foreign merchants in early modern Western European cities, like Bruges, Antwerp and Amsterdam. Urban elites did their best to attract and accommodate Italian, German and Iberian traders within their city walls, hoping that they would stimulate the urban economy. Here the migrants were temporary, wealthy and highly skilled. ${ }^{5}$ In their case the local 'membership regime' was characterized by 'open access', ${ }^{6}$ with the explicit aim to profit from the economic activities of Italian, German and Iberian traders. Citizenship was granted easily and urban institutions were open to them - very similar to high-skilled 'expats' in our current world. ${ }^{7}$ The reason commercial cities were so forthcoming is that they feared that merchants would otherwise move to a competitor. To avoid that, they were willing to lower transaction costs, offer protection and refrain from clamping down on merchants. ${ }^{8}$

These two examples have major repercussions for our understanding of the relationship between migration and social policies, here defined as 'actions that affect the wellbeing of members of a society through shaping the distribution of and access to goods and resources in that society'. ${ }^{9}$ In order to get a deeper understanding of this relationship, migration scholars first have to free themselves of a number of self-imposed limitations and take a much broader view, subsumed in the following three points:

1. Migration should include internal, temporary and high-skilled migrants.

2. Social policies should also be studied at the local level.

3. Social policies depend on the prevailing local and supra-local 'membership regime', of which the liberal-democratic expression is only one of many variants. ${ }^{10}$ 
To illustrate the added value of these three principles, I will first explain the recently developed cross-cultural migration rate (CCMR) method and then combine it with the historical 'membership regime' approach. ${ }^{11}$ Finally, I will show how (inclusive or exclusive) social policies, as part of broader membership regimes, have affected and have been affected by cross-cultural migrations in various parts of the world in the last 500 years.

\section{THE CCMR METHOD}

The cross-cultural migration rate (CCMR) indicates the chance for an individual to experience at least one cross-cultural migration in his or her life, which can be expressed as the share of the population in a certain territory (from a city to an empire or continent). ${ }^{12}$ The original formulation uses the following six categories that encompass all cross-cultural movements within a given territory ( $\mathrm{T}$ ) (irrespective of scale), measured in 50-year periods:

1. Immigration (people moving into $\mathrm{T}$ )

2. Emigration (people moving out of $\mathrm{T}$ )

3. To cities (within $\mathrm{T}$, generally from rural areas)

4. Colonization (moving to rural areas within $\mathrm{T}$ )

5. Seasonal (within $\mathrm{T}$, generally between peasant and farmer regions)

6. Temporal multi-annual [TMA] (soldiers, sailors, and artisans within T)

This migration typology harbors two different organizing principles. One is the differentiation between four key forms of cultural migration within a chosen geographical unit of analysis: the others consist of two logical categories that are necessary to calculate total migration rates: people leaving (emigration) or entering (immigration) that same geographical unit of analysis and who subsequently can be classified in one of the four core types. For a full understanding of the causes and effects of cross-cultural migrations within a given area, immigration and emigration therefore have to be 'unpacked'. Only then do we know how many of the immigrants or emigrants went to (or came from) cities or rural areas, and moved as soldiers, sailors or seasonal workers. The relationships between the six categories are shown in Figure 4.1.

The CCMR method explicitly differs from the mainstream approach in migration studies, which privileges one-way (A to B) movers, who cross international boundaries with the aim to settle at destination, and thus largely ignores return migrations, temporary migrants, circular and internal migrants. Not all scholars have been guided by such state definitions. Especially geographers and family historians, who are interested in micro-mobility or who take the household as the level of analysis, have done groundbreaking work on these other forms of migration and mobility, ${ }^{13}$ but their perspective has been incorporated in the field of mainstream migration studies only with difficulty. ${ }^{14}$ Moreover, these scholars are not, on the whole, interested in policy issues. ${ }^{15}$

The CCMR method not only builds on the approaches in historical demography and social geography, but is also inspired by Patrick Manning's idea of 'cross-community migration' as an engine of social change. ${ }^{16}$ The basic assumption behind this idea is that the prolonged interaction (peaceful, but also contentious and even violent) between 


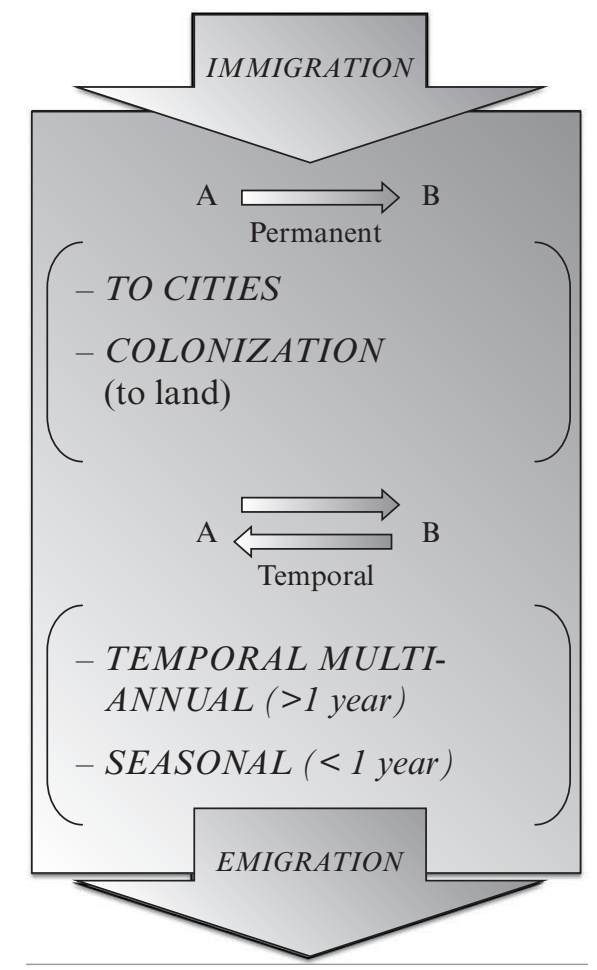

Figure 4.1 Cross-cultural migration rate (CCMR) method for a given territory and time period

people with different cultural backgrounds is bound to produce new ideas, insights and practices, and thus often leads to social change, in the broadest sense of the word, including the development of social policies. How this process evolves depends on power relations, status differentials and the specific (institutional) 'membership regime' of receiving societies. Following Benhabib, 'membership regime' is defined as 'the complex of rules, regulations, customs and values surrounding the entry and long-term settlement of migrants in a new polity'. ${ }^{17}$ In Manning's basic typology of cross-community migrants, the notions of power and multidirectionality are systematically anchored, as he distinguishes not only 'settlers' (the classical 'A-to-B-and-then-stay-migrant'), but also 'invaders, sojourners and itinerants'. ${ }^{18}$

When we want to understand the effects of migration on human societies and more specifically on the evolution of social policies, the cross-cultural migration perspective is a good point of departure. It enables structured comparisons in time and space, which so far have been largely lacking, due to the absence of an agreed definition of migration that is flexible enough to apply to different periods and world regions. Let me illustrate this with the example of young men and women from West African villages who migrate to European countries. Their moves clearly comply with the mainstream migration definition, as these people not only cross international but even continental borders. To understand the underlying mechanisms it is insightful to compare their migration patterns 
and motives with those of European young adults in the nineteenth (or earlier) century, who migrated from villages to a nearby (or more distant) city within their state, such as Bretons moving to Paris. ${ }^{19}$ Technically the latter are internal migrants, and as such fall under the radar of the mainstream migration historian. If we take the CCMR perspective, however, it is clear that the motives of West African migrants and the functionality of their strategic migration decisions within the household context are quite similar to those of internal migrants in European countries until very recently. The big difference is, of course, the obstacles that nation states have put in the way of free migration in the course of the twentieth century, which have increased the risks and costs considerably. ${ }^{20}$

\section{APPLYING THE CCMR METHOD TO EUROPE, 1500-2000}

So far the CCMR method has been applied to Europe and Russia, as well as large parts of Asia, and the method and data (broken down at the level of states) have been published in detail in various research papers and books. ${ }^{21}$ These results contradict a number of common-sense assumptions about the level and type of migrations in European and Asian societies. Let us first take a closer look at Europe in the period 1500-1900. As explained earlier, there has been a broadly shared consensus that in the nineteenth century a mobility transition took place as part of the broader 'modernization' process, which uprooted the assumed stationary and stable European societies - or, in the words of the geographer Wilbur Zelinsky in 1971,

Essentially, then, the universe of premodern, traditional communities was one of an array of cells firmly fixed in space with rather strong, if invisible, membranes surrounding each unit. Given the sturdiness of social ties, low levels of transport and communication technology, the sharply circumscribed mental horizons, and the minimal disposable incomes of most persons, it is scarcely surprising to find little beyond the most localized territorial mobility. ${ }^{22}$

Since the 1980s, however, historians have questioned the supposedly sedentary and immobile character of Europe, showing that the joint processes of commercialization, state formation (e.g. war) and globalization since the late fifteenth century created strong incentives for people to leave their places of birth, both permanently and temporarily. ${ }^{23}$ They moved as domestics, tramping artisans and casual workers in cities, mercenary soldiers in other parts of Europe, sailors all over the world, but also as colonists in remote areas of expanding empires, like Russia and the Ottoman and Habsburg empires. The CCMR method enables us to capture these mobilities and the trends over time, as shown in Figure 4.2.

Although these ratios constitute the bare minimum of the total mobility at the time, they make clear that there was no clear mobility transition in the nineteenth century that marked a dramatic change from an immobile to a mobile society. The level in the first half of the nineteenth century, for example, was scarcely higher than that two centuries earlier. Nevertheless, there is a substantial increase in the second half of the nineteenth century, which is linked to the transport revolution (cheap steamships and trains) ${ }^{24}$ and which enabled the migration of (predominantly) European rural folk to cities, both to the Americas (emigration) and within Europe (to cities). That Wilbur Zelinsky and others interpreted this increase as a fundamental transition is explained by their myopic view of 


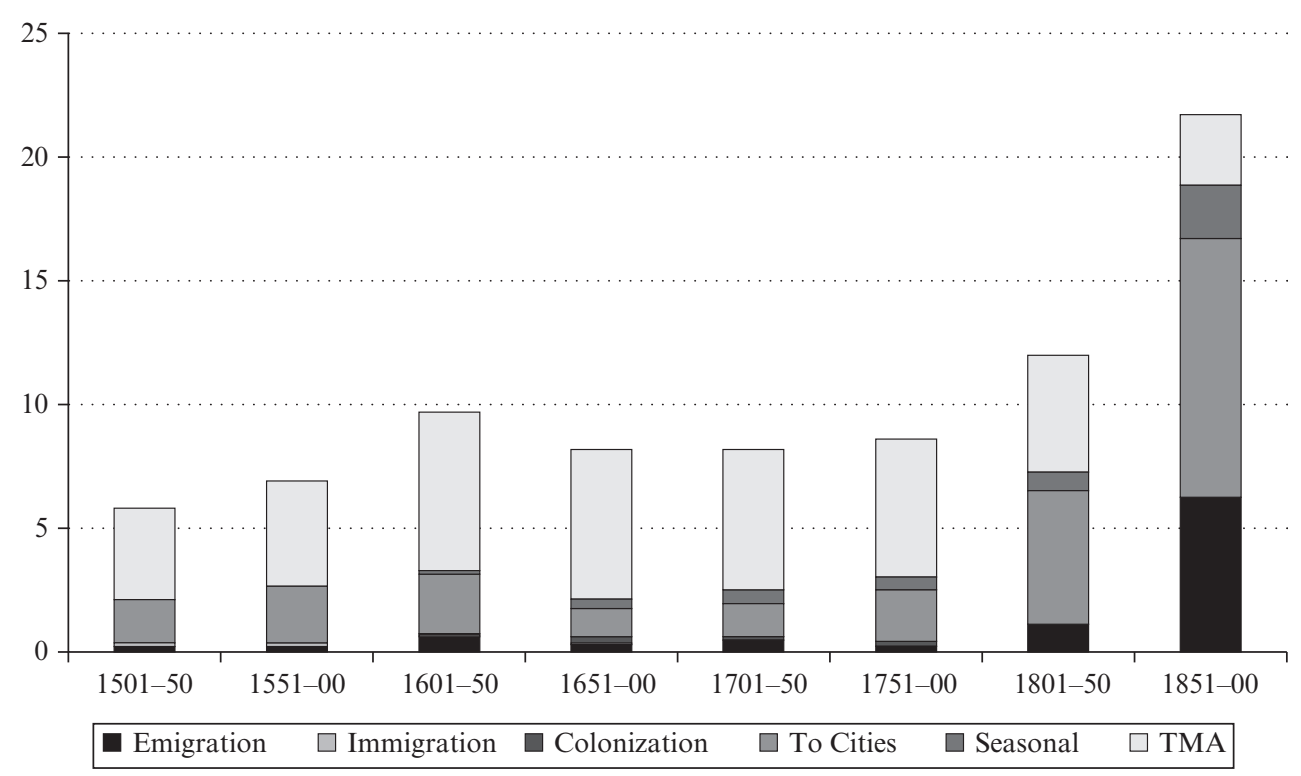

Source: Lucassen et al. (2014): table 170.

Figure 4.2 CCMRs for Europe (excluding European Russia), 1501-1900

migration, which was restricted to people leaving Europe and to the large rural-to-urban migrations, leading to a spectacular process of urbanization. In contrast to the doubling of the CCMR between 1800 and 1900 (Figure 4.2), a more conventional and limited view produces a much more dramatic change (and eightfold increase), as Figure 4.3 shows.

In the case of Zelinsky, this limitation was not primarily caused by a fundamentally different definition of what constitutes cross-cultural migration. Although he privileged permanent over temporary moves, as the following two quotes show, he also resisted the state-centered definition and rightly remarked that it was not primarily nationality or distance that mattered:

Genuine migration obviously means a perceptible and simultaneous shift in both spatial and social locus, so that the student cannot realistically measure one kind of movement while he ignores the other. Which family is more migratory, the one transferred 3000 miles across the continent by an employer to be plugged into a suburb almost duplicating its former neighborhood, or the black family that moves a city block into a previously white district? Ideally, we should observe shifts in both varieties of space in tandem, but given the dearth of techniques and data for handling purely social movement, we are forced to rely almost solely on territorial movements as a clumsy surrogate for total mobility. ${ }^{25}$

I therefore fully agree with his migration definition, but Zelinsky obviously did not realize how (quantitatively) substantial temporary and organizational migrations (primarily determined by the organizations people join) ${ }^{26}$ were in early modern Europe, especially by soldiers and sailors, as transpires from the following passage in his seminal 1971 paper: 


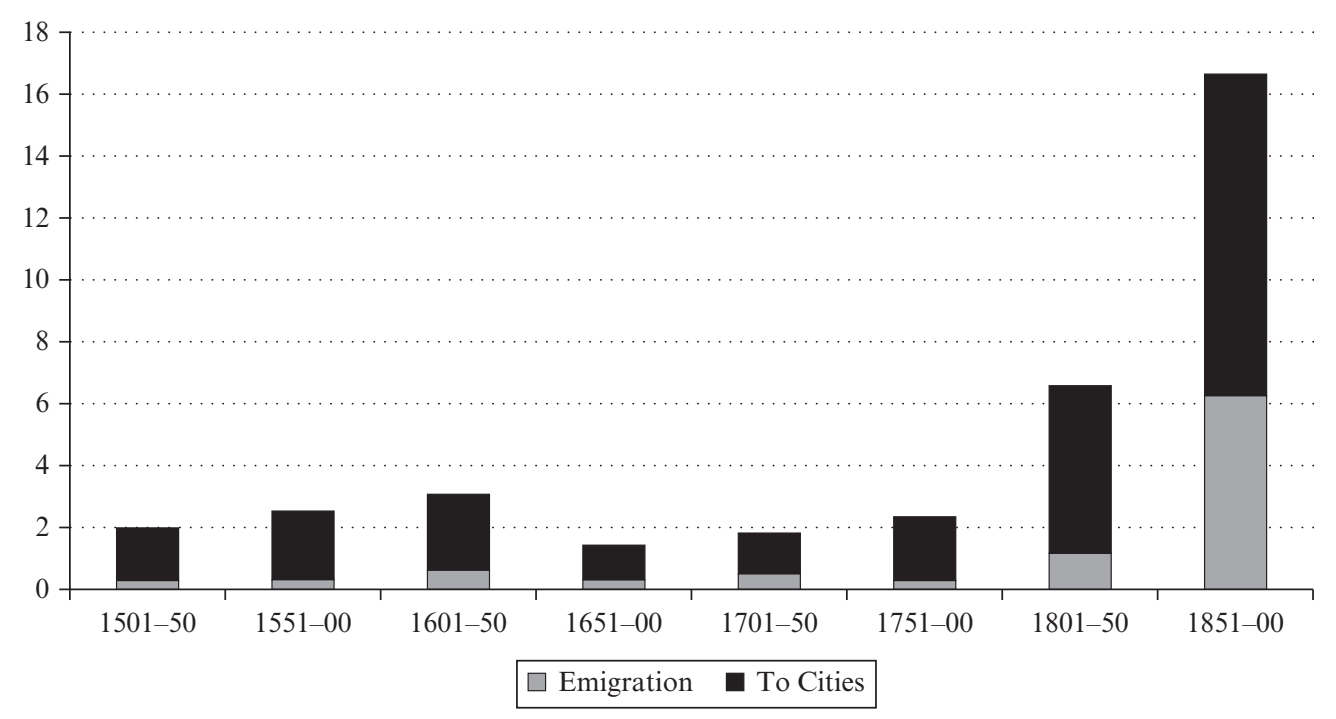

Source: Lucassen et al. (2014): table 170.

Figure 4.3 Migration rates, limited to urbanization and emigration in Europe (excluding European Russia), 1501-1900

The only persons freely to cross major social boundaries would be aristocrats, religious pilgrims and scholars, merchants, warriors, criminals, sailors, and so on, some of whom might elect to become full-fledged migrants or expatriates. ${ }^{27}$

What Zelinsky could not know at the time, due to the lack of research, was the ubiquity of seasonal, military and maritime migrations, as well as the normality of temporary and permanent moves to cities, which marked and changed the lives of millions of ordinary Europeans.

What then about the twentieth century, and more specifically our own time? Does the postwar period, with its second transportation revolution (cheap air travel) and the fading of racist (anti-Asian) migration regimes, ${ }^{28}$ indeed constitute the apogee of human cross-cultural mobility, as most social scientists claim? ${ }^{29}$ When we apply the CCMR method, the twentieth century indeed stands out, but differently than we would expect.

Figure 4.4 shows that, as far as we would like to think in terms of mobility transitions, the first half of the twentieth century ranks highest and not the more recent period. This all-time high is a culmination and acceleration of three trends: emigration to the Americas; continuing urbanization (within and between European states); and, last but not least, the cross-cultural experience of tens of millions of soldiers, both Europeans fighting and stationed in other countries and non-Europeans (especially Americans) active in Europe.

At this point many students of migration might raise their eyebrows. Why would one include soldiers as cross-cultural migrants in the first place? As far as there is interaction with others, one could argue, these contacts are a-personal, violent and often lethal, and barely involve intimate relationships or the forging of new social ties à la Zelinsky. ${ }^{30}$ 


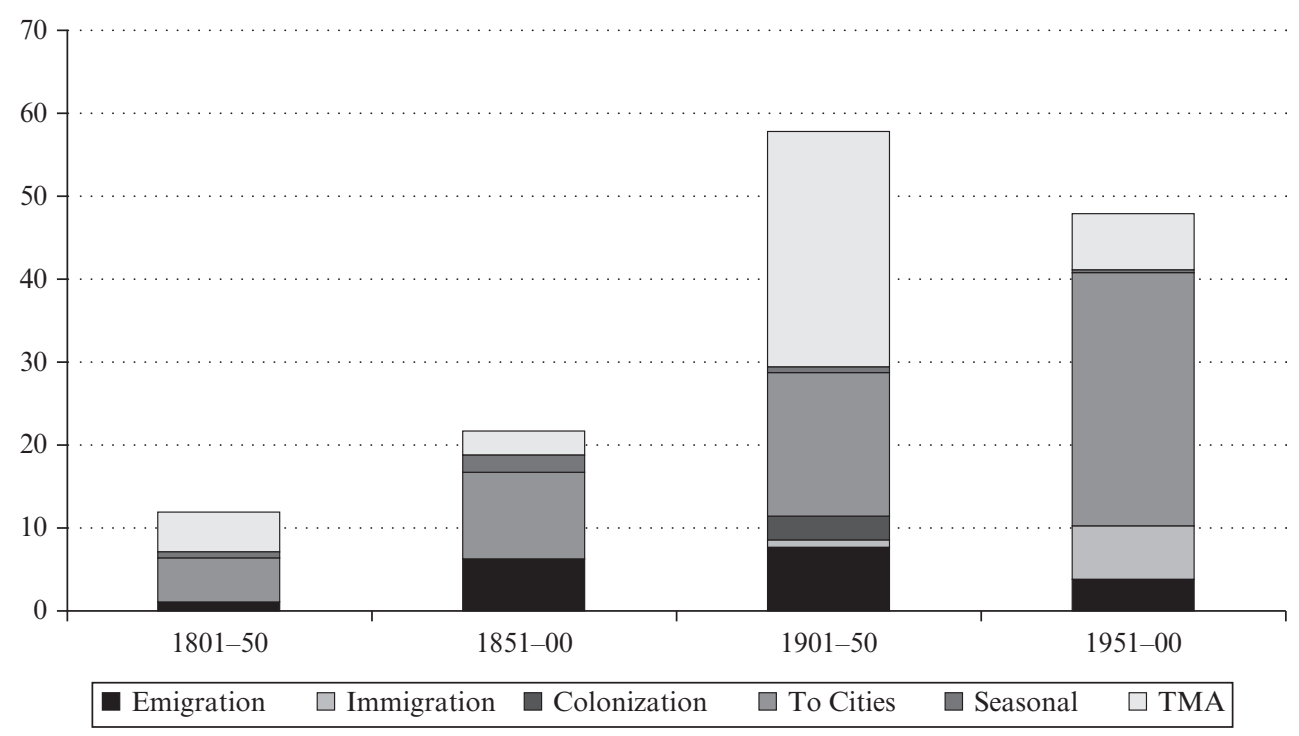

Source: Lucassen et al. (2014): table 170.

Figure 4.4 CCMRs for Europe (excluding European Russia), 1801-2000

Studies by military historians have shown, however, that soldiers who were sent to other countries, or to culturally different regions within empires, experienced probing and intensive encounters with other soldiers and civilians and confronted them with different cultures and socio-political systems. These interactions often had a pervasive impact on the way they perceived other cultures, as well as their own. And as a result the military experience changed many of them, as well as the societies they returned to.

Colonial warfare by metropolitan soldiers, for example, often strengthened asymmetrical and racist colonial relationships and stereotypes, and thus influenced postcolonial social policies, as in the case of Algerian migrants in France. ${ }^{31}$ During the traumatic and savage Algerian War (1954-62), some two million French soldiers were sent to North Africa (among whom Jean Marie le Pen), ${ }^{32}$ and their experiences led to a negative image of Algerians in general. When these soldiers returned after 1962, they had developed a strong anti-Algerian sentiment that was projected onto the Algerian migrants settling in large numbers in France in the postwar period. It needs no elucidation that this attitude informed social policies (especially concentrated and isolated housing) and complicated their integration process.

The sending of soldiers abroad could also have unexpected and transforming effects by raising a much more critical stance towards the socio-political systems in which soldiers were socialized. Examples are soldiers who become highly critical of the military project they were dispatched to accomplish. Many among the American forces in Vietnam lost their motivation, which undermined morale or even led to defections. Finally, soldiers can be exposed to a different social system that puts their own culture in a whole new light. A most instructive example is the experience of black GIs ${ }^{33}$ during, but especially 
after, World War II in Germany, where millions of Americans were stationed for at least two years as members of the occupation force and later on at American bases in Western Germany as part of NATO forces during the Cold War. ${ }^{34}$ For many of them the tour of duty in Europe was their first experience outside the USA, or even away from their home state. For African American soldiers this meant that they were confronted with non-segregated societies for the first time. To their great surprise, they could date white women and eat in restaurants alongside whites, without risking being lynched. These experiences in Europe had a huge impact and made them aware that what they had accepted as a normal situation was not natural at all. Although the US army upheld segregation within its own ranks, the absence of a color line outside the barracks sparked a process of awareness and social action, not only among US soldiers in Germany, but also among the black population after the soldiers returned and became active in the civil rights movement, which gave way to a much more encompassing 'Great Society' type of social policies, such as anti-poverty programs. ${ }^{35}$ Or in the prophetic words of the distinguished African American writer William Gardner Smith in 1947: after being treated as social equals, black American GI's would 'never go back to the old way again'. ${ }^{36}$ Another example is German soldiers who returned from the trenches after the Great War and whose experience had made them susceptible to national socialist ideas; many of them joined political right-wing associations (like Stahlhelm). ${ }^{37}$ In both cases, the cross-cultural experience changed social policies in their home countries, albeit in opposite (inclusive versus exclusive) ways.

For most migrating soldiers, encounters with others may have impacted their political persuasions less fundamentally than in the cases just discussed. Still, the socialization as young men in the army has many similarities with the migration experience. Especially in multi-ethnic empires, like Russia, China and the Habsburg and Ottoman empires, serving in the army meant temporary internal migrations over large distances and mingling with people who had very different cultural, religious, ethnic and linguistic backgrounds. And, moreover, it meant a new socialization process in an all-male authoritarian society in which radically different values and norms prevailed. ${ }^{38}$

Those readers who are still not convinced that the migratory experience of millions of soldiers really counts when we want to understand the relation between migration, social change and social policies can leave them out of the picture. The result of a more limited definition of cross-cultural migrations is that the trend is more in line with the conventional assumptions, yet for different reasons (see Figure 4.5).

This brings us to the second large category in the CCMR approach that might raise eyebrows as well: internal migrants moving to cities. As I explained earlier, the CCMR method does not distinguish between internal and international city dwellers. This means that, when we take Europe as the unit of analysis, someone who moved to London from a village some 30 kilometers from the capital is put in the same category as a Romanian peasant who decides to settle in Paris. Although there are obvious differences between the kind of cultural boundaries the two cross, they share a common primary socialization in village societies and subsequently the cross-cultural experience of having to adjust to city life, with different norms, values, institutions and networks. ${ }^{39}$ Moreover, until World War I, cultural differences within nation states, let alone empires, were still considerable, which makes the rural-urban divide a relevant boundary when it comes to the cross-cultural effects of migration. 


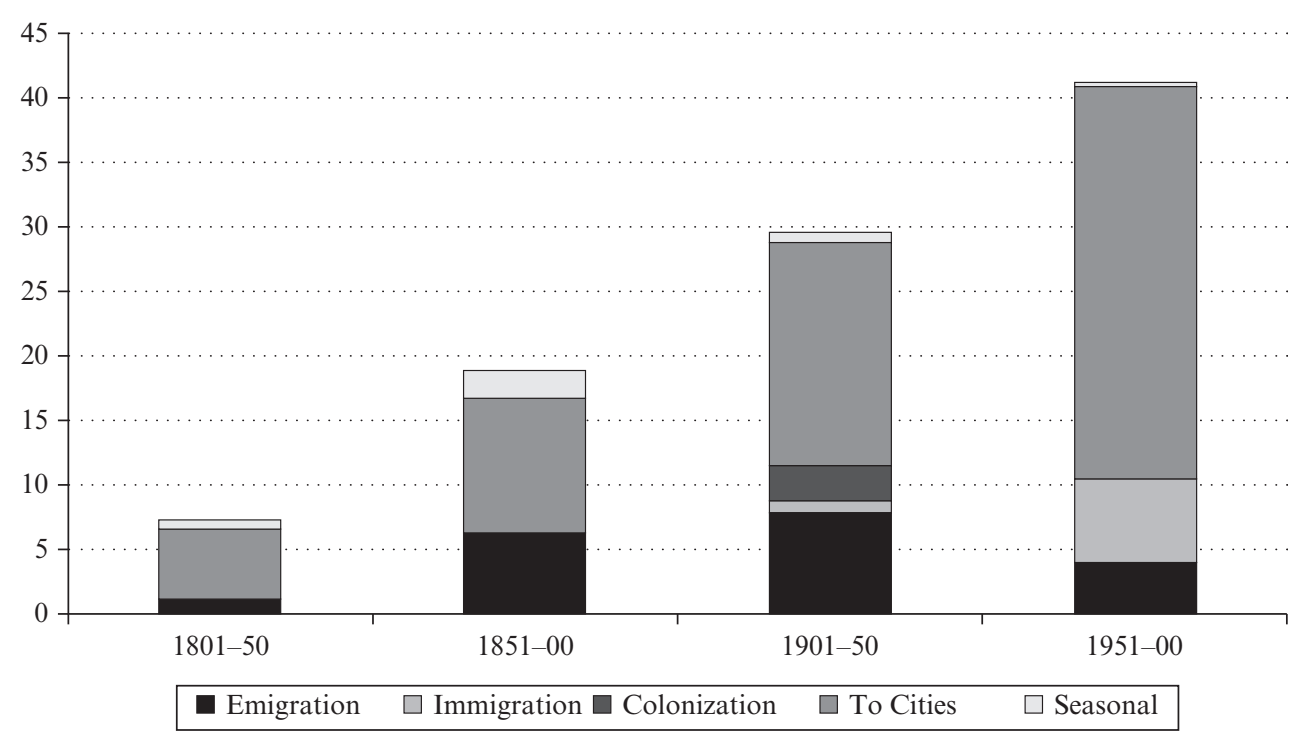

Source: Lucassen et al. (2014): table 170.

Figure 4.5 CCMRs for Europe (excluding European Russia), without TMA, 1801-2000

In the course of the twentieth century in most nation states the process of forging cultural homogeneity through the school, the army, radio and newspapers ${ }^{40}$ had effaced many cultural differences between people in the countryside and in villages. One could therefore argue that internal rural-to-urban migrations should no longer be considered as cross-cultural. In many countries, however, this process of cultural homogenization was far from finished in the twentieth century. Take for example the migration of Southern Italian peasants from the Mezzogiorno to North Italian industrial urban centers, like Turin and Milan, in the 1950s and 1960s. At the time they were considered as illiterate, culturally backward and even racially inferior people, whose 'invasion' would cause major social and cultural problems. ${ }^{41}$ For those who nevertheless would like to exclude migrants who moved to cities within their own state, the CCMR method makes it possible to distinguish between these internal migrants and those coming from other countries. Excluding the internal migrants in the twentieth century leads to the result shown in Figure 4.6.

Having adapted the CCMRs by leaving out soldiers and twentieth-century internal migrants moving to cities, the Europe's migration rates since 1850 prove remarkably stable, except for the postwar non-European immigrants, who caught most attention and explain why so many believe that migration is a recent phenomenon. Most of them come from the fringes of Europe: North Africa (Morocco, Algeria) and Turkey. The often-cited 'globalization' of recent decades is therefore less extensive than many assume. Although some nowadays speak of 'super-diversity', ${ }^{42}$ the large majority of the 'immigrants' could be called 'semi-Europeans', either because they come from areas that are adjacent to Europe or because they come from ex-colonies (South Asia, the Caribbean) where many 


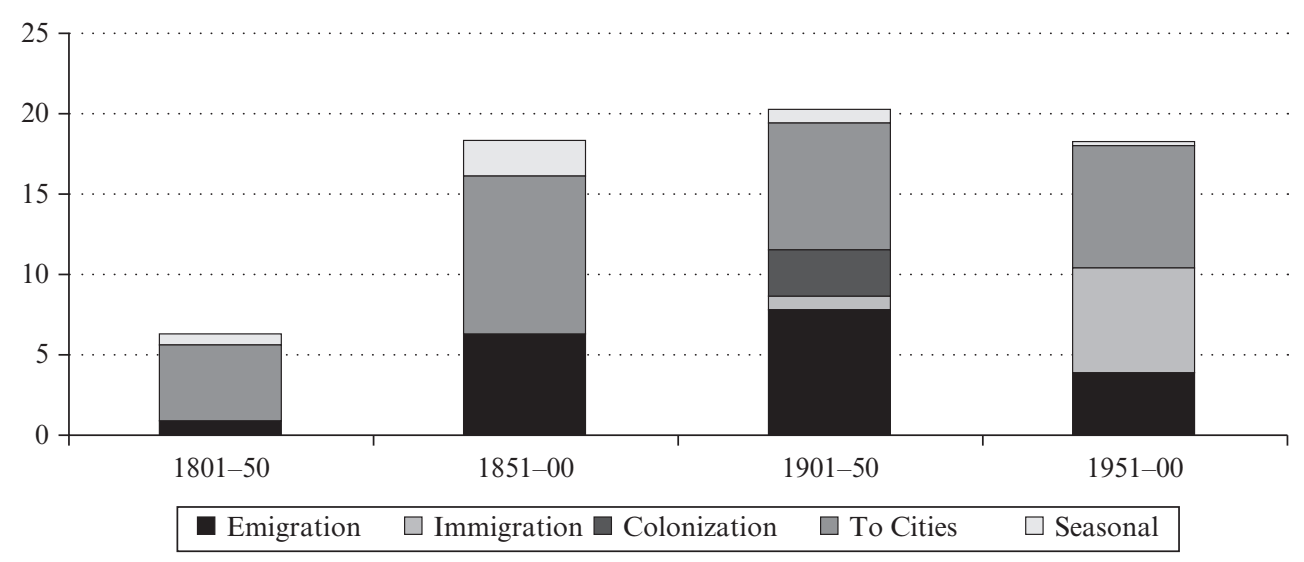

Source: Lucassen et al. (2014): table 168.

Figure 4.6 Total net CCMRs per category for Europe without Russia, excluding migrations to cities within nation states in the twentieth century and excluding soldiers and sailors, 1801-2000 (\%)

were already partially socialized (largely by organizational migrants from Europe) in terms of language, institutions and partly also religion (due to conversion).

\section{WHY BOTHER?}

What do we really gain by defining migration in a different, broader, less state-centered way and how is it related to social change? And do these new trends, and the new categories, explain what the conventional approach cannot? If we follow Manning, the crosscultural migrations are key to explaining 'social change', which in Manning's definition encapsulates more or less all aspects of human life, from economic to cultural changes, especially in the very long run - in other words: how people build societies, exploit natural resources, forge labor relations, classify and treat one another, anchor innovation, and develop world views. Social policies, meant to reduce all kind of risks, are an integral part of this broad canvas, and are intimately linked to the question who is included and who is not, at the local, regional or national level.

Manning's definition of 'social change' is quite similar to the neo-evolutionary approach of Ian Morris, whose most recent work sets out to explain differences in 'social development' between different parts of the world, in a somewhat shorter, but still considerable, time span of some 15000 years. Morris defines 'social development' as 'social groups' abilities to master their physical and intellectual environment and 'get things done in the world' ${ }^{43}$ Or more formally, social development is 'the bundle of technological, subsistence, organizational, and cultural accomplishments through which people feed, clothe, house, and reproduce themselves, explain the world around them, resolve disputes within their communities, extend their power at the expense of other communities, and defend themselves against other's attempts to extend power'. ${ }^{44}$ 


\section{Handbook on migration and social policy}

In order to measure and quantify social development, Morris distinguishes four characteristics: (1) energy capture (more or less efficient); (2) social organization (more or less complex, measured by city size); (3) war-making capacity; and (4) information technology (literacy, printing).

It should be stressed that social development can be evaluated very differently and is not intrinsically 'good' or 'bad'. Not only does such a value judgment depend on one's position and interests; it also hinges on how one appreciates the impact in the short or long run. The creolization in Latin America following the very unequal encounters and interactions between Spanish and Portuguese invading migrants and the native populations is definitely an example of social and cultural change that came at a huge cost and shaped highly differentiated (and discriminatory) social policies. The same is true of the interaction of Austrian political entrepreneurs, like Adolf Hitler, who introduced into German politics a specific Austrian anti-Semitic populism that had been developed in fin de siècle Vienna by politicians such as the Christian Social Mayor Karl Lueger..$^{45}$ No one can deny that the interaction of migrants like Hitler with German politicians led to political innovations and extremely racialized social policies, but many whole-heartededly deplore the outcome of this particular cross-cultural migration.

Although both Manning and Morris are primarily interested in (evolutionary) changes in the very long run and are not primarily focused on social policies, their approach is nevertheless useful for the readers of this book. To make their analytical tools more suited to the analysis of more recent social change and social policies, the 'human capability' approach, which inspired the creation of the UN's Human Development Index, was used. ${ }^{46}$ This methodology looks at per capita income, GDP, health (longevity, mortality and fertility), literacy and education, gender patterns, and savings investments and trade. The cross-spatial and cross-time variation of these indicators is in large part the result of different social policies. Finally, economic historians have measured similar indicators to map global developments in 'well-being' over the last two centuries. ${ }^{47}$

If we then integrate the various (long- and short-term) indicators and ask the question to what extent migration and migrants have caused social change/development in the societies of departure and arrival, and how it impacted migrants and non-migrants, we arrive at the scheme shown in Table 4.1, in which I distinguish between individual and collective levels.

Such a scheme has the advantage that we can look separately at changes for migrants at destination (on whom most studies concentrate) and at effects on the region of origin, to which they may return, or remain in contact through sojourning or transnational ties. Moreover, we can also include the effects of migration and cross-cultural contacts on those who stay put, either at destination or origin. Finally, at a more collective, societal level this approach offers us the opportunity to detect more structural and long-term changes in the social, cultural, economic and political characteristics of sending and receiving societies. 
Table 4.1 Collective and individual dimensions of social changeldevelopment caused by migration in societies of departure and arrival

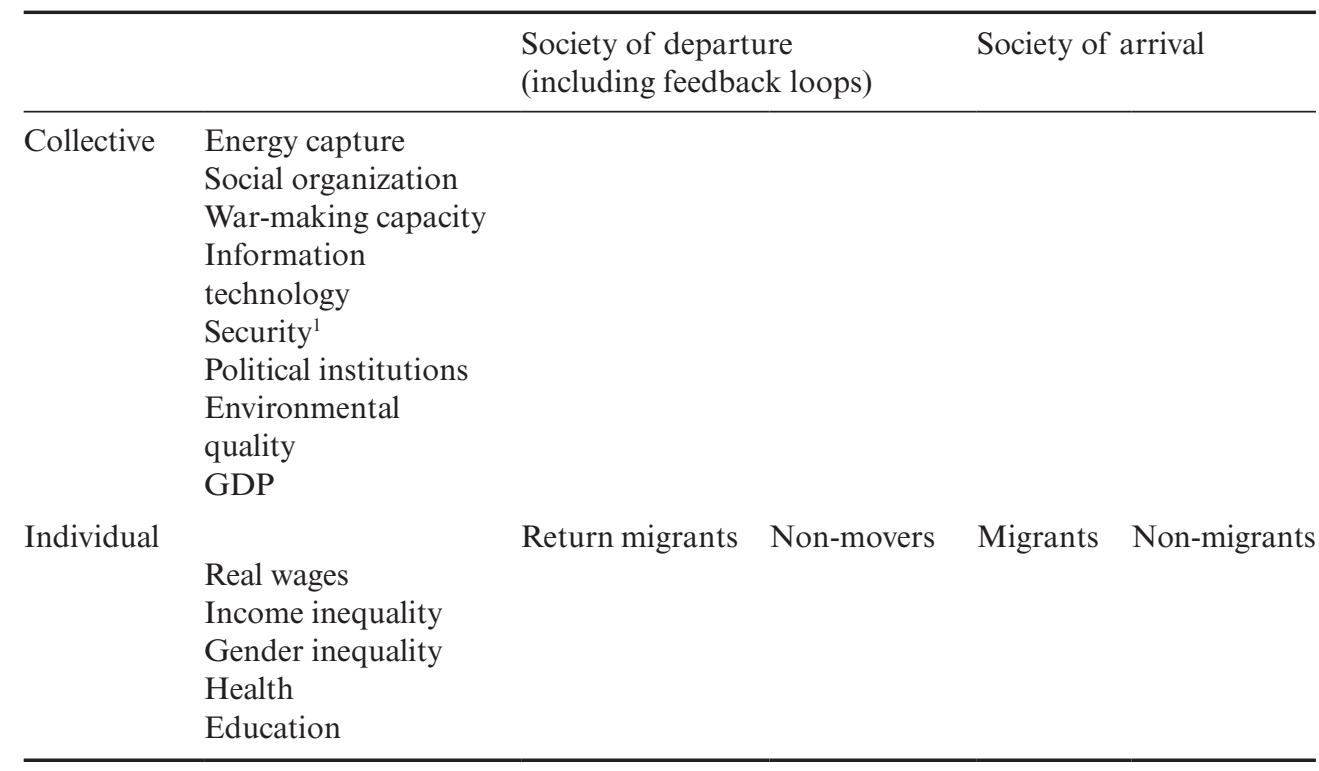

Note: $\quad{ }^{1}$ Measured by the level of criminality, e.g. the number of homicides per 100.000 inhabitants (in 2012, 1 for the Netherlands, 6 for the USA, 26 for Russia and 42 for South Africa).

\section{BUILDING STONES OF A THEORETICAL MODEL}

The CCMR method is a good but rough way to map the extent of geographical mobility in general, but also offers a starting point to understand the effects of different forms of 'cross-cultural migration'. A first step in developing a middle-range theory in which cross-cultural migration is studied as a cause of social change is to attribute 'weights' to the four basic types of CCMs (to cities, colonization, seasonal and TMA).

In general it seems not far-fetched to assume that migrations to cities in general have a greater impact and potential for change than colonization, because cities offer many more chances for interaction and harbor a much greater variety of cultures. Second, it can be assumed that seasonal migrations did change receiving societies, as they enabled the rural population at the destination to move to cities, but it seems that by far the biggest impact of seasonal migration was felt in the societies at origin, where the migrants returned each year. Due to the commodification of the labor power of peasants as seasonal migrants, their earnings were invested at home and thus stimulated commercialization and monetization processes by linking these economically less developed regions to the market economy. Temporal multi-annual migrations, finally, could have a considerable influence at both origin and destination (as we saw with the example of black American GIs), but this depends very much on the concrete situation. Less fuzzy is the role of high-skilled organizational migrants, such as missionaries, scholars and teachers. Especially in colonial settings, notwithstanding their limited numbers, their power and status were crucial 
Table 4.2 Attributing 'weights' for the positive effects to the four CCMs at the collective, societal, level

\begin{tabular}{lcc}
\hline & At origin & At destination \\
\hline To cities & 1 & 3 \\
Colonization & 0 & 1 \\
Seasonal & 2 & 1 \\
TMA & 3 & 3 \\
- Artisans & 1 & 1 \\
- Sailors & $1-3$ & 2 \\
- Soldiers in peacetime & $1-3$ & 0 \\
- Soldiers during wars & & \\
\hline
\end{tabular}

levers to forge change (in terms of language, religion, ideas and human capital). These considerations would lead to the following 'weights', with 0 as no effect on social change/ development, 1 small, 2 medium and 3 large. In Table 4.2 I have tried to come up with suggestions for such weights, limited to positive effects and to the collective, societal, level distinguished in Table 4.1.

This implies that, with similar CCMRs in, for example, Europe and China until the mid-twentieth century, the transforming effects of CCMs at destination in the former would still be larger because its CCMR consists of a much greater part of migration to cities and TMA.

If we limit ourselves to social policies, migration to cities (both internal and international) is key. Depending on the extent and nature of in-migration, cities (and from the twentieth century onwards nation states) have continuously shaped and adapted their settlement and citizenship policies. Whereas this is much less the case for seasonal migrations and colonization, TMA migrations also generated social policies, for example by states that created funds to cover costs of education, pensions and other social benefits (illness, unemployment) for soldiers and sailors. ${ }^{48}$

\section{Migrants' Capital}

In order to predict the impact of cross-cultural migrations, we should map the characteristics of the migrants in terms of symbolic capital (status), human capital (skills), ${ }^{49}$ social capital (networks), cultural capital (language, religion, world views), and military capital (power). Migration to cities by persons with high human capital will cause different changes than those with low skills, and the same is true for migrants with deviant ideas. To hypothesize about the conditions under which change takes place, the CCMs therefore have to be 'enriched' with migrants' capital. As an example of human capital one could take migrants to cities. It does matter whether they have acquired useful skills at origin, such as commercial skills (as peddlers) ${ }^{50}$ or technical skills (as artisans), or whether they were predominantly peasants. Moreover, we would also like to know to what extent people who moved to cities already had previous urban experiences and specific technical skills, as with many English workers who moved (temporarily and permanently) to North American industrial urban centers. ${ }^{51}$ 
And finally, as illustrated by the merchants in Bruges and Antwerp at the beginning of this chapter shows, the nature of such forms of 'capital' also largely determines social policies - open to high-skilled, closed to vagrants, and a gamut of more or less 'open access' in between. ${ }^{52}$

\section{Membership Regimes}

The third analytical tool necessary to build a theoretical model is the notion of 'membership regime', which links the CCMs' and migrants' capital to the prevailing complex of rules, regulations, customs and values surrounding the entry and long-term settlement of migrants in a new polity. ${ }^{53}$ And this is the level where social policies, either as a dependent or independent variable, become most visible, as they are part of the institutional opportunity structure at the local or national level and determine which 'members' have access to certain resources and who is excluded.

The reason for including the opportunity structure of the receiving polity in a middlerange theory on migration and social change is that the impact of CCMs depends largely on the specific opportunity structure at the receiving end. 'Moving to cities', to give just one example, occurred in many different ways. When migrants arrive in a city, they may be confronted with a highly segregated polity (the Chinese 'hukou' example) or one that is characterized by a relative 'open access regime'. The degree of openness of the receiving society, which, following the CCM logic, may be a city (to cities), an agricultural frontier, a plantation or labor camp (to land), an army, shipping company (TMA) or a commercial wage labor market (seasonal), determines to a large extent the chances for open exchange (and accumulation) of ideas and human capital. Membership regimes, embodied in social policies, are important because they determine the extent, intensity and equality of the interaction between migrants and the native population. If migrants are completely isolated, for example as chattel slaves or Asian guest workers in Gulf states, the chances of cross-cultural interaction are extremely limited. In situations in which we can speak of 'open access', however, as with the creative class in current global cities, ${ }^{54}$ the opposite is the case.

One type of membership regime that is often overlooked in migration studies is where migrants set the rules and therewith shape social policies. Although 'invading migrants' may forge major changes for those already present at destination (positive as well as negative), highly asymmetric power relations can nevertheless also limit social change. Take the example of Spanish conquistadores in Latin America in the fifteenth and sixteenth centuries. They imposed Spanish as the main language and Catholicism as the dominant religion. At the same time they shipped millions of Africans as slaves to the Caribbean in the sixteenth to nineteenth centuries. ${ }^{55}$ These migrants were not only exposed to hardship and death, but were also forced to convert, learn the language of their masters and give up most of their original culture. Although slaves had more agency than has long been assumed, and were to some extent able to hold on to their cultures and contribute to various forms of creolization, ${ }^{56}$ the extent of social change was limited. In both cases (the Amerindians and the African slaves), the result of the interaction seems predominantly the imposition of the invaders' culture and much less new outcomes. In terms of social policies, however, the invader type of migrations often had pervasive effects, especially by excluding and isolating the native population, as 


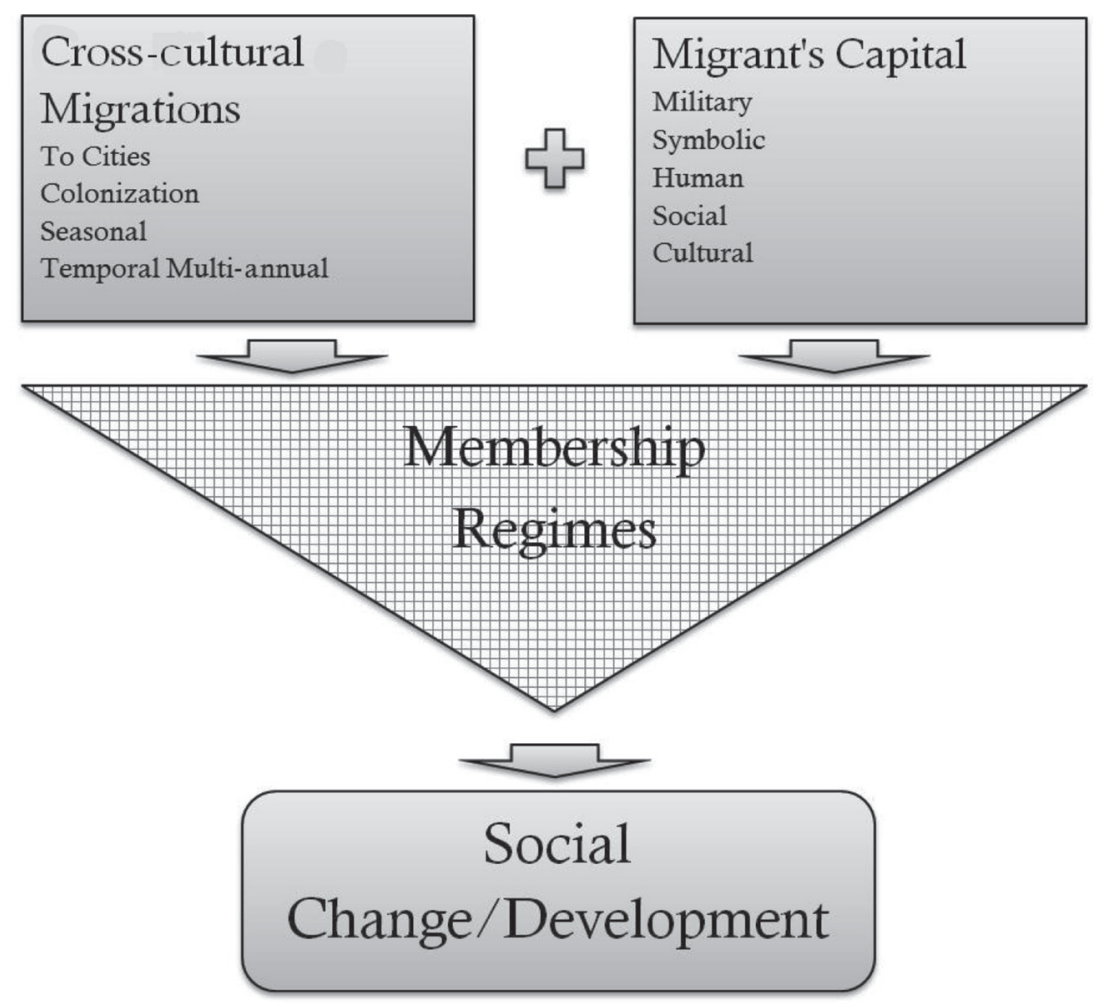

Figure 4.7 Schematic representation of the relation between cross-cultural migrations and social change

was the case in South Africa, the Americas and Oceania. They thereby treated them as second-rate citizens, at best.

Figure 4.7 summarizes the three analytical building blocks necessary to formulate a middle-range theory that aims to explain the impact of CCMs on receiving (and sending) societies in terms of social change or social development:

\section{CONCLUSION}

This chapter is a plea for a less state-centered definition of migration that allows us to understand much better the relationship between cross-cultural migrations (CCMs), social change and social policies. The CCMR method puts questions of social policies and citizenship in a much broader social context that includes internal migrations and a range of membership regimes, at the heart of which social policies decide who is included and who is not. How such policies develop, and who has access to poor relief, education, health care, the labor market and political institutions, differs widely in time and space. Moreover, the fault lines often go beyond national criteria. Racial, cultural, class and religious categories are at least as important. If we want to understand the relationship 
between migration and social policies, even if one limits oneself to long-term settlement (in terms of assimilation, integration or otherwise), ${ }^{57}$ the state gaze falls short. The power and interest of territorial states in controlling migration is a very recent phenomenon and only emerged in Western Europe and North America in the late nineteenth century when international migrations were nationalized and bureaucratized. ${ }^{58}$ Before that, migration controls were exerted much more at the level of cities or, especially in empires (like Russia), internally. ${ }^{59}$ Especially in early modern Europe, membership regimes were built locally, so that for comparisons that unveil the similarities and differences in the settlement process of migrants over time, the nation-state model has severe limitations.

As the examples of the hukou system and of high-skilled ('expat'-like) migrants at the beginning of this chapter showed, the CCMR method also helps to get a broader understanding of how migration and social policies are mutually constituting, at both destination and origin. In both examples, 'class' or 'human capital' largely decides who has access to social, cultural, economic and political institutions. Although human capital has become dominant in many parts of the world in the second half of the twentieth century, when it comes to which migrants are preferred, ${ }^{60}$ religion, nationality and race have not disappeared. This is the case even in the liberal democratic membership regimes that characterize Western Europe, North America and Oceania, but also in membership regimes that are much more exclusive or segmented, as we see nowadays in the policies toward foreign workers in the Gulf States, Japan and Malaysia, or towards internal migrants in parts of Asia and Africa. ${ }^{61}$ Our understanding of the relationship between migration and social policies in our own time is therefore greatly enhanced by taking a broader and more encompassing, global historical, view of migration.

\section{NOTES}

1. Based on a paper presented at the Elgar conference in Austin, University of Texas, 24-25 October 2014. An earlier version of this chapter was presented at the DEMIG conference in Oxford, 24 September 2014. I thank the commentators and colleagues at the Austin workshop for their comments.

2. Around 2010 , some 200 million Chinese (= 20 percent of the population) was officially defined as the 'floating population'.

3. Whyte 2010; Zhang and Wang 2010.

4. Hill and Gaddy 2003: 141-2; Werth 2004.

5. Gelderblom 2014.

6. North et al. 2009.

7. Favell 2008; Fechter and Walsh 2012.

8. Gelderblom 2014.

9. Cheyne et al. 2005: 3 .

10. Bosma et al. 2012. See also Lucassen and Willems 2012; De Munck and Winter 2012; Lucassen 2013.

11. Lucassen and Lucassen 2009; Lucassen and Lucassen 2014a, 2014b, 2014c; Bosma et al. 2012.

12. In relation to the population size of a given territory in a given time period, the total impact of geographical migration may be expressed in a formula: see Lucassen and Lucassen 2009.

13. With Ravenstein 1885 as an early representative. See also Châtelain 1956, 1976; Zelinsky 1971; Moch 1983; Ogden and White 1989; Rosental 1999; Farcy and Faure 2003.

14. See, e.g., Ogden and White 1989; Pooley aand Turnbull 1998; Kok 2004. Moch 2003 is one of the few scholars who systematically combines internal and international migrations in her analysis.

15. Important exceptions are Winter and Lambrecht 2013; King and Winter 2013.

16. Manning 2005, 2006, 2013.

17. Benhabib 2004; Bosma et al. 2013: 11.

18. Manning 2005: 8-9.

19. Moch 2012; De Haas 2010; De Haan 2006; Massey 1990. 


\section{Handbook on migration and social policy}

20. Cross 2013; Triulzi and McKenzie 2013.

21. Lucassen and Lucassen 2010; Lucassen et al. 2014; Lucassen and Lucassen 2014b.

22. Zelinsky 1971: 234 .

23. Well summarized in Moch 2003 and Bade et al. 2011.

24. Keeling 2012; Feys 2013.

25. Zelinsky 1971: 224.

26. Like the Church, diplomatic service, the army of a global company: Lucassen and Smit 2015 .

27. Zelinsky 1971: 234.

28. McKeown 2008

29. Castles and Miller 2003: 4.

30. See also Tilly 1978 .

31. Lucassen 2005.

32. Aldrich 1996: 297.

33. Goedde 2004: 517 writes that black GIs made up 6 percent of the American forces in Germany, which in the entire postwar period (1945-90) would have involved almost one million individuals (for total numbers see Höhn and Moon 2010).

34. Höhn 2002.

35. Skocpol 1988: 306

36. Höhn and Klimke 2010: 1 .

37. Schumann 2009: part III.

38. Sanborn 2005.

39. Lucassen 2013.

40. As described by Weber 1976 .

41. Mignone 2008: 216; Gabaccia 2000: 162 and 168. For France see Moch 2012.

42. Vertovec 2014 .

43. Morris 2013: 3

44. Ibid.: 5

45 Geehr 1990

46. Drèze and Sen 2013: $292 \mathrm{ff}$.

47. Van Zanden et al. 2014. The report looks at GDP per capita, real wages, education, life expectancy, human height, personal security (criminality), political institutions (democratic participation), environment quality, gender inequality and income inequality.

48. Skocpol 1992; Clark et al. 2003; Cowen 2008: 36; Eichenhofer 2007: 24

49. Van Lottum 2011; Van Lottum et al. 2011.

50. Van den Heuvel and Ogilvie 2013.

51. Berthoff 1953; Baines 1985.

52. Lucassen 2014.

53. In the end we will also have to include membership regimes at origin, because they have an impact on the various forms of capital of the migrants, as the example of the black American GIs shows.

54. Florida 2002

55. Wood 2011.

56. Price 1979. For a good summary of the discussion on 'social death' versus the reproduction of African cultures, see Sidbury 2011.

57. See Alba and Nee 2003; Lucassen 2005; Foner and Lucassen 2012.

58. Rosental 2011; McKeown 2008.

59. Torpey 2000; Garcelon 2001; Siegelbaum and Moch 2014

60. McKeown 2008.

61. Gardner 2010; Lucassen 2013; Ruhs 2013.

\section{REFERENCES}

Alba, R.D. and V. Nee (2003), Remaking the American Mainstream: Assimilation and Contemporary Immigration, Cambridge, MA: Harvard University Press.

Aldrich, R. (1996), Greater France. A History of French Overseas Expansion, Basingstoke, UK: Palgrave.

Bade, K.J., P. Emmer, L. Lucassen and J. Oltmer (eds) (2011), The Encyclopedia of Migration and Minorities in Europe. From the 17th Century to the Present, New York: Cambridge University Press.

Baines, D. (1985), Migration in a Mature Economy. Emigration and Internal Migration in England and Wales 1861-1900, Cambridge: Cambridge University Press. 
Benhabib, S. (2004), The Rights of Others. Aliens, Residents and Citizens, Cambridge: Cambridge University Press.

Berthoff, R.T. (1953), British Immigrants in Industrial America, 1790-1950, Cambridge, MA: Harvard University Press.

Bosma, U., G. Kessler and L. Lucassen (eds) (2013), Migration and Membership Regimes in Global and Historical Perspective, Leiden and Boston: Brill.

Castles, S. and M.J. Miller (2003), The Age of Migration. International Population Movements in the Modern World, New York: The Guilford Press.

Châtelain, A. (1956), 'La formation de la population lyonnaise. Les courants de migrations au milieu du XXe siècle d'après le fichier électoral', Revue de Géographie de Lyon, 31, 199-208.

Châtelain, A. (1976), Les migrants temporaires en France de 1800 à 1914, Villeneuve d'Ascq: PUL.

Cheyne, C., M. O'Brien and M. Belgrave (2005), Social Policy in Aotearoa New Zealand: A Critical Introduction, Oxford: Oxford University Press.

Clark, R.L., L.A. Craig et al. (2003), A History of Public Sector Pensions in the United States, Philadelphia, PA: University of Pennsylvania Press.

Cowen, D. (2008), Military Workfare: The Soldier and Social Citizenship in Canada, Toronto: University of Toronto Press.

Cross, H. (2013), 'Labour and underdevelopment? Migration, dispossession and accumulation in West Africa and Europe', Review of African Political Economy, 40 (136), 202-18.

De Haan, A. (2006), 'Migration, gender, poverty: family as the missing link', in S. Arya and A. Roy (eds), Poverty, Gender and Migration, New Delhi: Sage Publications, pp. 107-28.

De Haas, H. (2010), 'The internal dynamics of migration processes: a theoretical inquiry', Journal of Ethnic and Migration Studies, 36 (10), 1587-617.

De Munck, B. and A. Winter (eds) (2012), Gated Communities? Regulating Migration in Early Modern Cities, Aldershot, UK: Ashgate.

Drèze, J. and A. Sen (2013), An Uncertain Glory: India and Its Contradictions, London: Allen Lane.

Eichenhofer, E. (2007), Geschichte des Sozialstaats in Europa: von der 'sozialen Frage' bis zur Globalisierung, Munich: Beck.

Farcy, J.C. and A. Faure (2003), La mobilité d'une génération de Français: recherche sur les migrations et les déménagements vers et dans Paris à la fin du XIXe siècle, Paris: Institut National d'Études Démographiques.

Favell, A. (2008), Eurostars and Eurocities: Free Movement and Mobility in an Integrating Europe, Malden, MA: Blackwell Publishing.

Fechter, A.-M. and K. Walsh (eds) (2012), The New Expatriates: Postcolonial Approaches to Mobile Professionals, London: Routledge.

Feys, T. (2013), The Battle for the Migrants. The Introduction of Steamshipping on the North Atlantic and its Impact on the European Exodus, St John's, Newfoundland: International Maritime Economic History Association.

Florida, R. (2002), The Rise of the Creative Class . . and how it's Transforming Work, Leisure, Community, and Everyday Life, New York: Basic Books.

Foner, N. and L. Lucassen (2012), 'Legacies of the past', in M. Crul and J. Mollenkopf (eds), The Changing Face of World Cities. Young Adult Children of Immigrants in Europe and the United States, New York: Russell Sage, pp. $26-43$.

Gabaccia, D. R. (2000), Italy's many Diasporas, London: UCL Press.

Garcelon, M. (2001), 'Colonizing the subject: the genealogy and legacy of the Soviet internal passport', in J. Caplan and J. Torpey (eds), Documenting Individual Identity. The Development of State Practices in the Modern World, Princeton, NJ: Princeton University Press, pp. 83-100.

Gardner, A. (2010), City of Strangers: Gulf Migration and the Indian Community in Bahrain, Ithaca, NY: ILR Press.

Geehr, R.S. (1990), Karl Lueger: Mayor of Fin de Siecle Vienna, Detroit: Wayne State University Press.

Gelderblom, O. (2014), Cities of Commerce. The Institutional Foundations of International Trade in the Low Countries, 1250-1650, Princeton, NJ: Princeton University Press.

Goedde, P. (2004), 'Gender, race and power. American soldiers and the German population', in D. Junker (ed.), The United States and Germany in the Era of the Cold War, 1945-1990: A Handbook, Cambridge: Cambridge University Press, pp. 515-21.

Hill, F. and C.G. Gaddy (2003), The Siberian Curse: How Communist Planners Left Russia Out in the Cold, Washington, DC: The Brookings Institution.

Höhn, M. (2002), GIs and Fräuleins: the German-American Encounter in 1950s West Germany, Chapel Hill, NC and London: The University of North Carolina Press.

Höhn, M. and M. Klimke (2010), A Breath of Freedom: The Civil Rights Struggle, African American GIs, and Germany, New York: Palgrave Macmillan. 


\section{Handbook on migration and social policy}

Höhn, M. and S. Moon (eds) (2010), Over There: Living with the U.S. Military Empire from World War Two to the Present, Durham, NC: Duke University Press.

Keeling, D. (2012), The Business of Transatlantic Migration between Europe and the USA, 1900-1914, Zürich: Chronos.

King, S. and A. Winter (eds) (2013), Migration, Settlement and Belonging in Europe 1500-1930s. Comparative Perspectives, New York and Oxford: Berghahn Books.

Kok, J. (2004), 'Choices and constraints in the migration of families. Central Netherlands 1850-1940', History of the Family. An International Quarterly, 9 (2), 137-58.

Lucassen, L. (2005), The Immigrant Threat: The Integration of Old and New Migrants in Western Europe since 1850, Urbana and Chicago, IL: The University of Illinois Press.

Lucassen, L. (2013), 'Population and migration', in Peter Clark (ed.), The Oxford Handbook of Cities in World History, Oxford: Oxford University Press, pp. 664-82.

Lucassen, L. (2014), 'To Amsterdam: migrations past and present', in J.W. Duyvendak, N. Foner, J. Rath and R. v. Reekum (eds), Immigration and the New Urban Landscape: New York and Amsterdam, New York: New York University Press, pp. 52-81.

Lucassen, J. and L. Lucassen (2009), 'The mobility transition revisited, 1500-1900: what the case of Europe can offer to global history', The Journal of Global History, 4 (4), 347-77.

Lucassen, J. and L. Lucassen (2010), 'The mobility transition in Europe revisited, 1500-1900: sources and methods', IISH Research Papers, Amsterdam, The Netherlands: International Institute of Social History, pp. 44-126.

Lucassen, J. and L. Lucassen (2014a), 'Measuring and quantifying cross-cultural migrations: an introduction', in idem (eds), Globalising Migration History. The Eurasian Experience (16th-21st Centuries), Leiden, The Netherlands and Boston, MA: Brill, pp. 3-64.

Lucassen, J. and L. Lucassen (eds) (2014b), Globalising Migration History. The Eurasian Experience (16th-21st Centuries), Leiden, The Netherlands and Boston, MA: Brill.

Lucassen, L. and J. Lucassen (2014c), 'Quantifing and qualifying cross-cultural migrations in Europe since 1500: a plea for a broader view', in F.A. Fauri (ed.), The History of Migration in Europe: Perspectives from Economics, Politics and Sociology, London and New York: Routledge, pp. 1-34.

Lucassen, L. and A.X. Smit (2015 forthcoming), 'The repugnant other: soldiers, missionaries and aid workers as organizational migrants', The Journal of World History.

Lucassen, L. and W. Willems (eds) (2012), Living in the City. Urban Institutions in the Low Countries, 1200-2010, New York: Routledge.

Lucassen, L., R. de Jong, J. Lucassen and M. van de Water (2014), 'Cross-cultural migration in Europe 1901-2000: a preliminary estimate', IISH Research Papers, Amsterdam: International Institute of Social History.

Manning, P. (2005), Migration in World History, New York and London: Routledge.

Manning, P. (2006), 'Homo sapiens populates the earth: a provisional synthesis, privileging linguistic evidence', The Journal of World History, 17 (2), 115-58.

Manning, P. (2013), Migration in World History, 2nd edn, Abingdon, UK and New York: Routledge.

Massey, D.S. (1990), 'Social structure, household strategies and the cumulative causation of migration', Population Index, 56, 2-26.

McKeown, A. (2008), Melancholy Order: Asian Migration and the Globalization of Borders, New York: Columbia University Press.

Mignone, M.B. (2008), Italy Today: Facing the Challenges of the New Millennium, New York: Peter Lang.

Moch, L.P. (1983), Paths to the City: Regional Migration in Nineteenth-century France, Beverly Hills, CA: Sage.

Moch, L.P. (2003), Moving Europeans: Migration in Western Europe since 1650, Bloomington, IN: Indiana University Press.

Moch, L.P. (2012), The Pariahs of Yesterday: Breton Migrants in Paris, Durham, NC: Duke University Press.

Morris, I. (2013), The Measure of Civilization: How Social Development Decides the Fate of Nations, Princeton, NJ: Princeton University Press.

North, D.C., J.J. Wallis and B.R. Weingast (2009), Violence and Social Orders. A Conceptual Framework for Interpreting Recorded Human History, Cambridge: Cambridge University Press.

Ogden, P.E. and W.P.E. White (eds) (1989), Migrants in Modern France: Population Mobility in the Later 19th and 20th Centuries, London: Unwin Hyman.

Pooley, C.G. and J. Turnbull (1998), Migration and Mobility in Britain since the Eighteenth Century, London: UCL Press.

Price, R. (ed.) (1979), Maroon Societies: Rebel Slave Communities in the Americas, Baltimore, MD: Johns Hopkins University Press.

Ravenstein, E.G. (1885), 'The laws of migration', Journal of the Statistical Society, 48, 167-235.

Rosental, P.A. (1999), Les sentiers invisibles: espace, familles et migrations dans la France du 19e siècle, Paris: Éditions de l'École des Hautes Études en Sciences Sociales. 
Rosental, P.A. (2011), 'Migrations, souveraineté, droits sociaux. Protéger et expulser les étrangers en Europe du XIXe siècle à nos jours', Annales HSS, 2, 335-73.

Ruhs, M. (2013), The Price of Rights: Regulating International Labor Migration, Princeton, NJ: Princeton University Press.

Sanborn, J.A. (2005), 'Unsettling the empire: violent migrations and social disaster in Russia during World War I', The Journal of Modern History, 77 (2), 290-324.

Schumann, D. (2009), Political Violence in the Weimar Republic, 1918-1933: Fight for the Streets and Fear of Civil War, New York: Berghahn Books.

Sidbury, J. (2011), 'Resistance to slavery', in G. Heuman and T. Burnard (eds), The Routledge History of Slavery, London and New York: Routledge, pp. 204-19.

Siegelbaum, L. and L.P. Moch (2014), Broad is My Native Land: Repertoires and Regimes of Migration in Russia's Twentieth Century, Ithaca, NY and London: Cornell University Press.

Skocpol, Theda (1988), 'Federal government and employment', in Margaret Weir, Ann Shola Orloff and Theda Skocpol (eds), The Politics of Social Policy in the United States, Princeton, NJ: Princeton University Press, p. 480 .

Skocpol, T. (1992), Protecting Soldiers and Mothers: The Political Origins of Social Policy in The United States, Cambridge, MA: Harvard University Press.

Tilly, C. (1978), 'Migration in modern European history', in W.H. McNeill and B. Adams (eds), Human Migration. Patterns and Policies, Bloomington, IN: Indiana University Press, pp. 48-72.

Torpey, J. (2000), The Invention of the Passport. Surveillance, Citizenship and the State, Cambridge: Cambridge University Press.

Triulzi, A. and R. McKenzie (eds) (2013), Long Journeys: African Migrants on the Road, Leiden, The Netherlands: Brill.

Van den Heuvel, D. and S. Ogilvie (2013), 'Retail development in the consumer revolution: the Netherlands, c. 1670-c. 1815', Explorations in Economic History, 50 (1), 69-87.

Van Lottum, J. (2011), 'Labour migration and economic performance: London and the Randstad, c. 16001800', Economic History Review, 64 (1), 1-20.

Van Lottum, J. et al. (2011), 'Sailors, national and international labour markets and national identity', in R.W. Unger (ed.), Shipping and Economic Growth 1350-1850, Leiden, The Netherlands and Boston, MA: Brill, pp. 309-52.

Van Zanden, J.L., J. Baten et al. (2014), How was Life? Global Well-being since 1820, Geneva: OECD Publishing. Vertovec, Steven (2014), Superdiversity, London and New York: Routledge.

Weber, E. (1976), Peasants into Frenchmen: The Modernization of Rural France, 1870-1914, Stanford, CA: Stanford University Press.

Werth, N. (2004), 'The Russian card: the Propiska', in C. Watner and W. McElroy (eds), National Identification Systems: Essays in Opposition, New York: McFarland and Company, pp. 116-19.

Whyte, M.K. (ed.) (2010), One Country, Two Societies: Rural-Urban Inequality in Contemporary China, Cambridge, MA: Harvard University Press.

Winter, A. and T. Lambrecht (2013), 'Migration, poor relief and local autonomy: settlement policies in England and the Southern Low Countries in the eighteenth century', Past \& Present, 218, 91-126.

Wood, B. (2011), 'The origins of slavery in the Americas', in G. Heuman and T. Burnard (eds), The Routledge History of Slavery, London and New York: Routledge, pp. 64-79.

Zelinsky, W. (1971), 'The hypothesis of the mobility transition', The Geographical Review, 61 (2), 219-49.

Zhang, L. and G.-X. Wang (2010), 'Urban citizenship of rural migrants in reform-era China', Citizenship Studies, 14 (2), 145-66. 
